\title{
From Classificatory Theories to Social Darwinism and Western Manipulation in the World
}

\author{
Sınıflandırma Teorilerin'den Sosyal Darvinizm'e \\ Dünyada Batı Hegomanyası
}

\section{M. Önder GÖNCÜOĞLU*}

\begin{abstract}
In order to understand how the expansion of an empire means more than geographical expansion, the whole process of both the eighteenth century classificatory system and nineteenth century Social Darwinism should be taken into account. We must therefore consider how the European viewed the non-European as the wild and 'the other'; how they legitimised the idea of the white man's superiority over 'the other'. Only then can some certain texts written under the influence of such thinking be perceived in a wider scope with certain causes and results as well. Such thinking regarding 'the other' related both to the scientific classification system of the eighteenth century and to Social Darwinism as the prevailing ideology of the late nineteenth century milieu. Therefore, the primary goal of this article is to clarify how such western thinking was first moulded and then galvanized through scientific proofs to make the idea of the inferiority of the non-European "other" common among Europeans.
\end{abstract}

Keywords: Classification, Social-Darwinism, empire, 'the other'

Özet: Bir imparatorluğun genişlemesinin coğrafi yayılımının ötesinde bir olgu olduğunu anlayabilmek için on sekizinci yüzyıla ait sınıflandırma sisteminin ve on dokuzuncu yüzyılda ortaya atılan Sosyal Darvinizm teorisinin dikkate alınması gerekir. Bununla beraber Avrupa'lının Avrupa'lı olmayanı nasıl 'yabani' ve 'öteki' olarak gördüğ̈̈ ve buna paralel 'beyaz adam üstünlügü'nü nasıl 'öteki' üzerinde meşrulaştırdığ da göz önüne alınmalıdır. Ancak o zaman, bu düşünce biçiminin etkisi altında kaleme alınmış metinlerin bağlamları, sebep ve sonuçları bakımından daha iyi analiz edilebilir. Bu sınıflandırma sistemi ve Sosyal Darvinizmin on dokuzuncu yüzylla gelindiğinde 'öteki’ni değerleyen baskın ideoloji biçimini oluşturduğu görülmektedir. Bu nedenle, bu makalenin temel amacı batı merkezli böyle bir ideolojinin nasıl şekillendiğini göstermek ve batılı olmayan 'ötekiler'in daha aşağı türler olduğu zemininin bilimsel çarpıtmalarla nasıl oluşturulduğunu kanıtlamak olacaktır.

Anahtar Sözcükler: Sinıflandırma, Sosyal-Darvinizm, imparatorluk, 'öteki'

After the main steps taken in the sixteenth century with several discoveries in distant lands; the seventeenth century was, undoubtedly, the most determining period for Western and particularly, British imperialism. Therefore, the significance of the seventeenth century in terms of its providing a convenient basis for the establishment of a more self-aware and even more systematised British Empire requires no affirmation. In other words, the idea of a civilizing mission, the moral superiority of the white race, mercantilism and the use of martial force to triumph over new lands and to offer safety for the territories already occupied, were all fullydefined in the seventeenth century. According to P. J. Marshall (1998), during the period between 1689 and 1815, "both the area and the number of people under British rule increased greatly."

\footnotetext{
*PhD., Ege University, English Language and Literature, İzmir, nafonder@yahoo.com
} 
Then, he adds, "British governments began to concern themselves with colonial issues and to commit resources to overseas war on an unprecedented scale" (Introduction, 1).

In this account, the seventeenth century witnessed the beginnings of large scale British settlement, especially in North America and parts of the Caribbean. When it was the end of the seventeenth century, "a new concept of Empire", therefore, "had been established, which involved the assertion of dominion over foreign places and peoples, the introduction of white, and also black, settlement in these areas, and the monopolizing of trade with these newly acquired possessions" (Canny, 1998, 22). This adoption of the concept of settlements increased in scope and pace over the course of the eighteenth century. However, along with immense geographical growth, western classificatory theories were accordingly galvanized in the eighteenth century to enable some ideological theories such as Social Darwinism, be formed in late nineteenth century.

Actually, classificatory theories before the eighteenth century had undoubtedly created an idea of the westerner's superiority over the non-Westerner. Yet, the systematizing of nature in the eighteenth century became a European project of a new kind, a new form of what one might call, in Pratt's words, "planetary consciousness among Europeans" $(1992,29)$. The process of European knowledge-making had already been operating, above all, in navigational terms. In this respect, according to Pratt (1992), these terms gave rise to two totalising or planetary projects: "one was circumnavigation, a double deed that consists of sailing round the world, then writing an account of it" (29). Undoubtedly, Europeans had been repeating this double deed almost continually since it was first started by Magellan in the 1520s. However, the second planetary project, according to Pratt (1992): "was the mapping of the world's coastlines, a collective task that was still underway in the eighteenth century, but known to be" feasible (29).

It is explicit that the concept of an "Empire of Europe" in the sixteenth and seventeenth centuries extended almost "to the utmost bounds of the earth, where several of its nations have conquests and colonies" (Marshall, 1998, 48). Circumnavigation and mapmaking, then, had already given rise to what one might call a European global or planetary subject. Literarily, the work of Daniel Defoe, Robinson Crusoe (1719), in this regard, may be taken as one of the first elements exemplifying this new form of planetary consciousness because Defoe's literary vision makes clear that this world's most significant historical subject is European, male, secular, and lettered. His planetary consciousness is the product of his contact with print culture and more complete at the time than the lived experiences of sailors. Therefore, there is no doubt that the contact with print culture had a significant influence on the planetary consciousness that also resulted in the establishment of the notion of imperialism either as its justification or critique of it. Moreover, not ignoring print culture also reveals how classificatory systems in general framed convenient imperial tendencies (Pratt, 1992, 30).

With regard to the justification of imperialism, the verbal representation of the classification of the earth through mapping "not just of coastlines or rivers, but of every visible square, or even cubic, inch of the earth's surface" (Pratt, 1992, p. 29) resulted in a totalizing perception. By this same token, as Buffon argues: "Alongside this totalising embrace, how timid seems the old navigational custom of filling in the blank spaces of maps with iconic drawings of regional curiosities and dangers - Amazons in the Amazon, cannibals in the Caribbean, camels in the Sahara, elephants in India, and so on" (Pratt, 1992, 30).

The eighteenth century classificatory systems, then, created the task of locating every species on the planet, extracting from its particular, arbitrary surroundings, and placing it in its appropriate place in the system but with its new written, European classificatory name. As a result of this, one by one the planet's life forms were inscribed into European-based patterns of global unity and order. In other words, as Marshall (1998) states: "the lettered, male, European 
eye that held the system could familiarize new sites/sights immediately upon contact, by incorporating them into the language of the system" (52). In addition, because Britain was ahead of all other European powers, her navigational mapping and classification of lands and species, by this regard, outnumbered all the rest of the European powers.

Western classificatory system, as a way of thinking, interrupted other existing networks of historical and material relations among people, plants and animals wherever it applied itself. Yet the fact that the European observer himself had spared for himself a superior place in this description is also worth evaluating here. This place of superiority is justified in the following categorization of Linnaeus (1758), where he posited among the quadrupeds (four-footed), a single category homo, implying 'Know thyself':

a) Wild Man. Four-footed, mute, hairy.

b) American. Copper-colored, choleric, erect. Hair black, straight, thick; nostrils wide; face harsh; beard scanty; obstinate, content, free. Paints himself with fine red lines. Regulated by customs.

c) European. Fair, sanguine, brawny; hair yellow, brown, flowing; eyes blue; gentle, acute, inventive. Covered with close vestments. Governed by laws.

d) Asiatic. Sooty, melancholy, rigid. Hair black; eyes dark; severe, haughty, covetous. Covered with loose garments. Governed by opinions.

e) African. Black, phlegmatic, relaxed. Hair black, frizzled; skin silky; nose flat; lips tumid; crafty, indolent, negligent. Anoints himself with grease. Governed by caprice.

f) Monster. Dwarfs and giants (Since the giants of Patagonia were still a firm reality as well as man-made monsters like eunuchs): (Burke, 1994, 266).

What is explicit about this categorization of humans is easy to notice as it is clearly comparative. Through this categorization the myth of European superiority is naturalised. On the other hand, Burke's following finding is stunning since he underlines that the fact of this superiority myth is still valid: "Except for the monsters and wild men, the classification exists barely modified in some of today's (1994) school books" (1994, 266). Hence, one can now see how navigational mapping used the power of naming to categorise species newly discovered or observed anew. With the aid of this mapping, both geographically and racially, religious and geographical projects came together. By this same token, the world itself was baptised as landmarks through Euro-Christian names.

At the level of ideology, these classificatory systems, as Buffon clarifies, "created global imaginings above and beyond commerce. It operated as a rich and multifaceted mirror onto which all Europe could project itself as an expanding planetary process, exploitation and violence being carried out by commercial and political expansion and colonial domination" (Pratt, 1998, 33). The systematizing of nature, in this regard, represents not only a European discourse about non-Europeans worlds, but also an urban discourse about non-urban worlds or a lettered, bourgeois discourse about non-lettered, peasant worlds $(1998,33)$. Therefore, it could justifiably be argued that the systems of nature were projected within European borders as well as beyond those borders.

Moreover, when we regard the time period of this systematizing of nature, we deduce that it preceded the onset of the Industrial Revolution. Therefore, this systematizing process coincided with the height of the slave trade, the plantation system, and colonial exploitation. The slave trade and the plantation system as experiments in social engineering and discipline, in serial 
production and the systemization of human life, and also even in the standardizing of persons all resulted in the establishment of industrial capitalism (Pratt, 1998, 35). It is for this reason that, according to Pratt (1998), "economic historians sometimes call the years 1500-1800 the period of "primitive accumulation"' (36), where, through slavery, European bourgeoisies were able to collect the capital that started the Industrial Revolution. Last but not least, within the same process, while the first elements of industrial capitalism were being launched, the same wave of images started to shape urban mass society in Europe under bourgeois hegemony. Accordingly, there appeared a picture of the world that was appropriated and arranged from a unified, European perspective.

Undoubtedly, prior to the eighteenth century, Europeans mostly believed that societies on Earth were in a state of decline and European societies assumed that the pre-Ottoman worlds of ancient Greece and Rome were standards to aspire to. It is for this reason that Ancient Greece and Ancient Rome served accomplishments that Europeans of the Middle Ages sought to emulate, for they were continually longing for the lost Golden Age. Moreover, Christianity, at the same time, taught -and still does preach- that people lived in a decadent world fundamentally inferior to the Garden of Eden and Heaven. During the Age of Enlightenment, however, European secularist and humanist self-confidence grew and the notion of progress became highly popular and thinkers, whom today we would refer to as social and academic intellectuals, started speculating that societies progressed through the stages of increasing development, and they argued that all societies passed through several stages, such as hunting and gathering, including stages of pastoralism, nomadism, agriculturalism, and commerce. They therefore, looked for the logic, order, and scientific truths underlying determined human history. Hegel, for instance, believed that social development was an inevitable and predetermined process. Therefore, it was thought that societies start out primitive in a state of nature, as Hobbes assumed, and that they naturally progress towards something parallel to industrial Europe.

Theories of sociocultural evolution allowed Europeans to organise their new knowledge in a way that reflected and justified their growing political and economic control of others, which in practice resulted in the idea that colonized peoples were less evolved and colonizing people were more evolved. Unsurprisingly, then, the seventeenth century English philosopher Thomas Hobbes described primeval man as living in conditions in which there are no arts, no letters, no society, living a life solitary, poor, nasty, brutish, and short. He was, in a sense, announcing and justifying a popular conception of the so-called savage. Everything that was good and civilised therefore stemmed from a gradual progress from this low state (Grafton, 1992, p. 113). However, the issues shaping the notion and the application of the ideas of the primitive and of progress were not discussed sterilely in accordance with certain scientific views.

Having been bolstered by the systematizing of nature, and by early theories of classifications especially during the period of New Imperialism in the second half of the nineteenth century a new form of colonialism and racism, were then not surprising. Actually, it is worth focusing on this, for whereas Darwin's idea of evolution was highly scientific and not publicized until 1859 , the idea of evolution was already a social phenomenon fostered through such classificatory theories, which in a sense was in need of a biological ground to support it. Therefore, the cartoon drawn by John Leech (1849) and displayed in "Punch", which is much before Darwin's theory was publicised, foreshadowed evolution in an ironical way through the child's words, 'Mamma, look dere! Dere Papa!': 


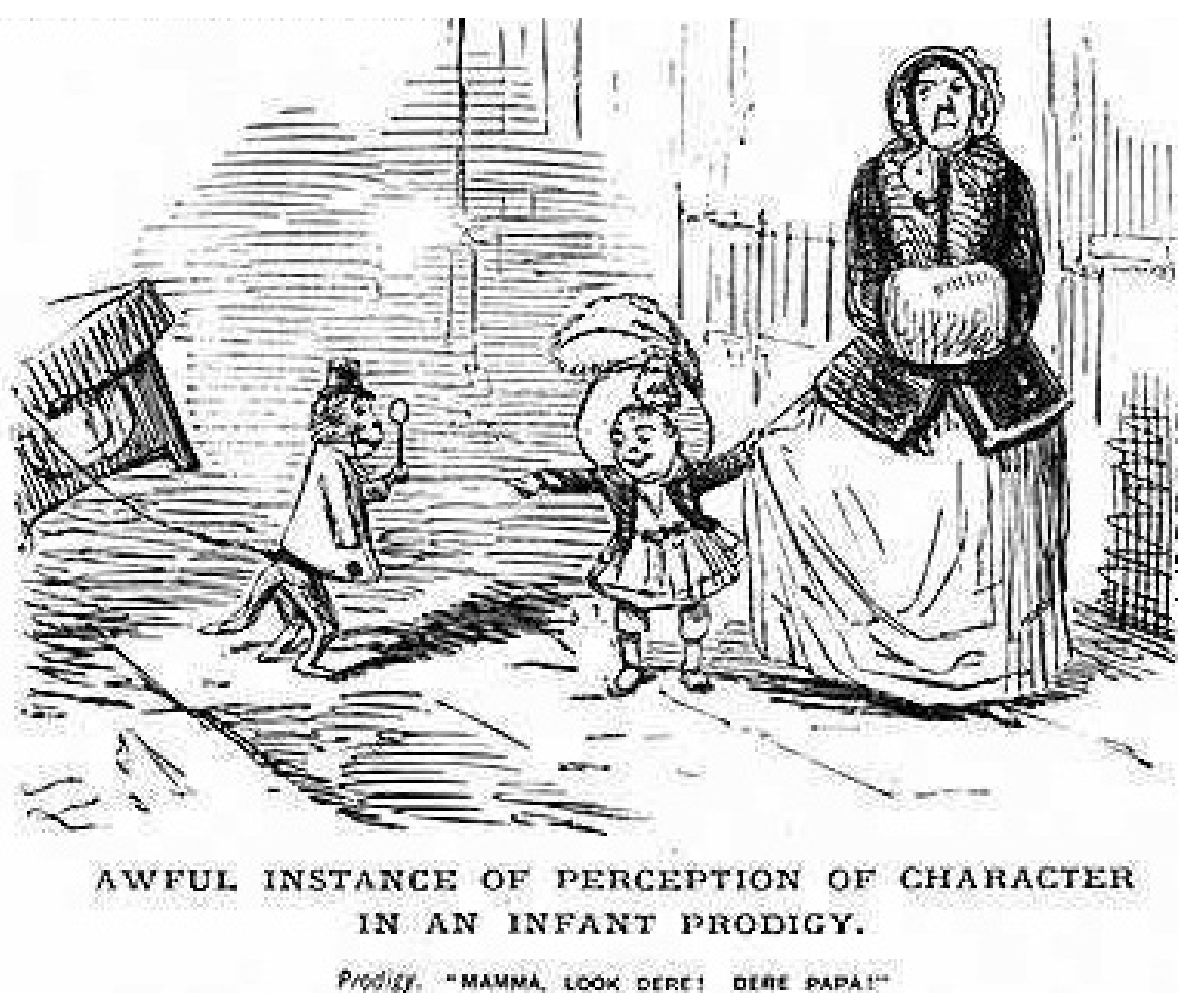

Figure 1. ("Punch")

Moreover, it was not only the cartoons of the era but also British newspapers, and circus and exhibition advertisements in general, that dealt with such concepts of evolution and of nonwestern types of beings. Consequently, all these newly met concepts highly shaped the perceptions of the public with a curiosity and also a fear for non-Western and unfamiliar life forms. Therefore, when time evolved into the nineteenth century, sociocultural evolutionism had become the prevailing theory of early sociocultural anthropology, along with an abiding attempt to formalise social thinking along scientific lines.

After such a long tradition of colonialism and misidentification what is clear is that the popularity of classificatory theories in the seventeenth and eighteenth centuries coincided with a period of European expansion in the world. Such theories particularly fostered racism. Some scientific theories widespread especially after the 1860 s became very effective in merging a perception of the 'Aryan race' as dominant over the other races. Therefore, the awareness of the concept of superiority took its full shape within the nineteenth century with the changing nature of attitudes towards race. It is for sure that the work of nineteenth century scholars such as Robert Knox (1791-1862), Charles Darwin (1809-1882), and Edward Burnett Tylor (18321917) became very influential in the new perception of attitudes towards race.

In this respect, the sense of European and particularly British superiority in the nineteenth century differed from that of the eighteenth century. Philip Curtin, a historian on the Africa and the Atlantic Slave Trade, has noted: "Whereas in the eighteenth century an English sense of national superiority was grounded in religious difference and general xenophobia, in the nineteenth century evidence of supremacy in factory production, agricultural yield, and elaborate systems of transportation led to different explanation of expanding hegemony" (Deirdre, 1995, 88). England was, undoubtedly, supreme in all things, not just in banking, shipbuilding, and insurance. Therefore, this belief, according to Curtin, led to the creation of a racially oriented view of human beings and their civilisations and also a kind of racial pyramid with Europeans on top 
emerged $(1975,88)$. As for the changing nature of attitudes towards race in the nineteenth century, Douglas Lorimer argues:

Before 1860, ethnocentrisms dictated belief in cultural superiority, an attitude that sometimes grudgingly admitted the possibility of a subjugated people being educated, or civilized, so that it, too might conform to the superior norm; but that after 1859 belief in cultural and social superiority began to derive its dubious authority from theories of biological difference, popularly appropriated from Darwin's Origin of Species $(1988,89)$.

In addition to Douglas Lorimer and Philip Curtin, another historian, Andrew Porter, who also studied European imperialism, in his introduction to the volume on the nineteenth century of the Oxford History of the British Empire observes that racial superiority was taken for granted from mid-century onwards by ordinary English Victorian people. According to Porter, this belief was extremely influential because it was this belief that strengthened the ties of the different parts of a wide-ranging geopolitical empire. How the ordinary Victorian man perceived the savage individual, so-called, and, conversely, regarded the Empire's civilising mission, Porter (1999) describes as follows:

From the outbreak off the Indian rebellion in 1857 via the Morant Bay riots in Jamaica in 1865 and the opening of the Suez Canal in 1869 through the first sitting of a Maori parliament in New Zealand in 1892, the ordinary Victorian found much evidence of 'native' barbarism and Anglo-Saxon success in 'civilizing' once 'savage' peoples... and AngloSaxon belief in the inevitable ascendancy of its own race received confirmation in what was seen as the equally inevitable extinction of indigenous peoples, either through cultural assimilation or through annihilation as the result of disease and war (22).

It is not surprising to see that these historians, having studied the attitudes towards race in nineteenth century, have taken the year 1860 as the starting point of a radical factor in the tendencies toward the issue of race. As stated above, Darwin's Origin of Species was published in the year 1859. Then his second most famous and controversial work, The Descent of Man, was published in 1871. In The Descent of Man, Darwin discussed many related issues, including evolutionary psychology, evolutionary ethics, differences between human races, differences between human sexes, and the relevance of the evolutionary theory to society. Moreover, this significant work was highly influential particularly upon Victorian man since Darwin opened a new epoch with his famous assertion that preceding naturalists had great difficulty in trying to decide how many races there actually were:

Man has been studied more carefully than any other animal, and yet there is the greatest possible diversity amongst capable judges whether he should be classed as a single species or race, or as two (Virey), as three (Jacquinot), as four (Kant), five (Blumenbach), six (Buffon), seven (Hunter), eight (Agassiz), eleven (Pickering), fifteen (Bory St. Vincent), sixteen (Desmoulins), twenty-two (Morton), sixty (Crawfurd), or as sixtythree, according to Burke. This diversity of judgment does not prove that the races ought not to be ranked as species, but it shows that they graduate into each other, and that it is hardly possible to discover clear distinctive characters between them (Blake, 1989, 91). 
Therefore, the changing nature of attitudes towards race in the late nineteenth century period was basically constructed upon the idea that there must be permanent racial divisions. The optimistic assumption that human nature was everywhere identical, and that generous governance might transform barbaric cultures, also began to decline. And in place of this optimism, Victorian people began to think more negatively about a racial world elsewhere. In sum, late nineteenth century thinking about race tended to shift from the construction of a hierarchy of societies based on differences in culture to the invention of a hierarchy based on differences in race. This new outlook of the collective consciousness became a prime subject matter in the scholarship of the late nineteenth century. For instance, Robert Knox, who posited sub-racial divisions by national origin types, considered English Anglo-Saxons superior to all others and attributed all historical change to racial inequality (Blake, 1989, 91).

Furthermore, "human-zoos", during which various human beings were presented in cages during colonial exhibitions, manipulated western thinking to a large extent and fostered racism at a high pace. Thus, human zoos became an important means of supporting "popular racism", while being at the same time an object of anthropology; those zoos were sometimes called "ethnographic exhibitions" or even "Negro villages" (91). The display of human beings in cages to demonstrate scientific racist theories became so common in the second half of the nineteenth century only after European-oriented classificatory systems -mentioned above- established a proper background. For instance, the 1889 World's Fair in Paris had a "Negro Village" where 400 indigenous people were displayed. Moreover, Carl Hagenbeck, a German merchant, exhibited 'Samoans' with wild animals in 1874. Yet this was not all, since Madison Grant, as the head of the New York Zoological Society (Tucker, 2002, 54), exhibited Ota Benga, a Congolese pygmy, at the Bronx Zoo in New York City in 1906, alongside apes and other animals. When this Congolese pygmy, named Ota Benga, was placed in a cage with an orangutan and labelled as "The Missing Link" by Grant, Grant intended to illustrate in evolutionary terms that Africans were like Ota Benga and were closer to apes than were Europeans (54).

Social evolutionism, influenced by the biological theory of evolution, represented an attempt to formalize social thinking along scientific lines. As for those ethnographic zoos, it should be particularly noted, emphasised the growing belief that indigenous people, particularly Africans, were placed in a scale somewhere between the great apes and human beings of European descent (54). At this point it is also worth citing historian Pascal Blanchard's (2005) words that, referring to 'human zoos', attempted to clarify how the so-called superiority of the Aryan race and its colonial discourse were moulded and thereby legitimised:

Human zoos, the incredible symbols of the colonial period and the transition from the nineteenth to twentieth century, have been completely suppressed in our collective history and memory. Yet they were major social events. The English, the French, Europeans and Americans came in their tons of millions to discover the 'savage' for the first time in zoos or 'ethnographic' and colonial fairs. These exhibitions of the exotic (the future 'native') laid the foundations on which, over an almost sixty-year period, was spun the West's progressive transitions from a 'scientific' racism to a colonial and 'mass' racism' affecting millions of 'visitors' from Paris to Hamburg, London to New York, Moscow to Barcelona (Tucker, 2002, 19).

Such ethnographic zoos were often attributed to unilinealism, a version of Social Darwinism (Poliakov, 1974, 340). Social Darwinism, basically speaking, was composed of many competing theories by various sociologists and anthropologists, who believed that Western culture was the contemporary apex of social evolution. Famous thinkers of the age such as Thomas 
Malthus (1766-1834), Francis Galton (1822-1911), Edward Burnett Tylor (1832-1917), Lewis Henry Morgan (1818-1881), and Herbert Spencer (1820-1903) supported the idea that Western culture was the contemporary pinnacle of social evolution (341). As is now well known, the concepts of "survival of the fittest" and "natural selection" explain the two major mechanisms of Darwinism that drive human cultural, social, and political evolution. Moreover, these concepts later began to be interpreted by the Social Darwinists to justify the exploitation, domination, and subordination of other races qualified as inferior. According to them, nations and races were engaged in a struggle for survival in which only the fittest would survive. Being one of those Social Darwinists, and also a naturalist, Alfred Russel Wallace in 1864 put forth his own theory regarding the European superiority in the following words:

The intellectual and moral, as well as the physical qualities of the European are superior; the same power and capacity which have made him rise in a few centuries from the condition of a wandering savage ... to his present state of cultural advance ... enable him when in contact with savage man to conquer in the struggle for existence and to increase at his expense (Perry, 2008, 623).

It can be deduced from Wallace's declaration that Social Darwinism provided a moral justification for the domination and exploitation of man by man, thereby regarding domination and exploitation as the natural right of the superior race. These Social Darwinists employed a war of physical, economic, cultural, and psychological blockage against a cross section of mankind. Colonialism and imperialism became major manifestations of this battle against others. Such battles have always occurred in human history, but now by mid-century during the 1800 s, the West had a scientific explanation for such centuries-old human conduct. As Perry (2008) argues, "When European statesmen gathered in Berlin in 1884 to officially partition Africa among themselves, they were fully consumed by this spirit of racial superiority. This was why they made it an obligation to "civilize" the "primitive" Africans" (Perry, 2008, 614).

From the Social Darwinist perspective, it was natural for African and American lands to be invaded for western economic enterprise. It was natural for the natives to be humiliated, enslaved, and killed in capitalist mines and or on plantations. Social Darwinism reduced the indigenous peoples to a plain object, what historian Walter Rodney (1982) calls "a specimen" worthy of examination under a microscope (Rodney, 1982, 294). The full implication of Social Darwinism was that it was 'unnatural' to be African, American Indian, Asiatic or briefly any non-European and if nature made the mistake of creating such 'inferior races', their role was to carry the 'white man's burden'. With the growing influence of Social Darwinism, therefore, both the representation of the indigenous peoples as such as inferior to the civilized white man and also the idea of evolution concerning 'natural selection' began to be dealt with in the magazines of the period. Below the cartoon by J. B. Patridge (1893) published in "Punch", depicts the heyday of Social Darwinism; a dialogue between a British tourist and a "Negro waiter" is ironically represented. The allusions in the cartoon can be considered to be taking place in two dimensions. The first is that of a social scale: "the black" deserves to be inferior; hence, his only role is to serve. The second dimension concerns evolution; that is, the British tourist orders a quail and is served a pig's foot. Therefore, although the perplexed tourist complains about the order as he thinks it was mistaken, the waiter insists on its being a quail, suggesting an evolution in his thinking: 


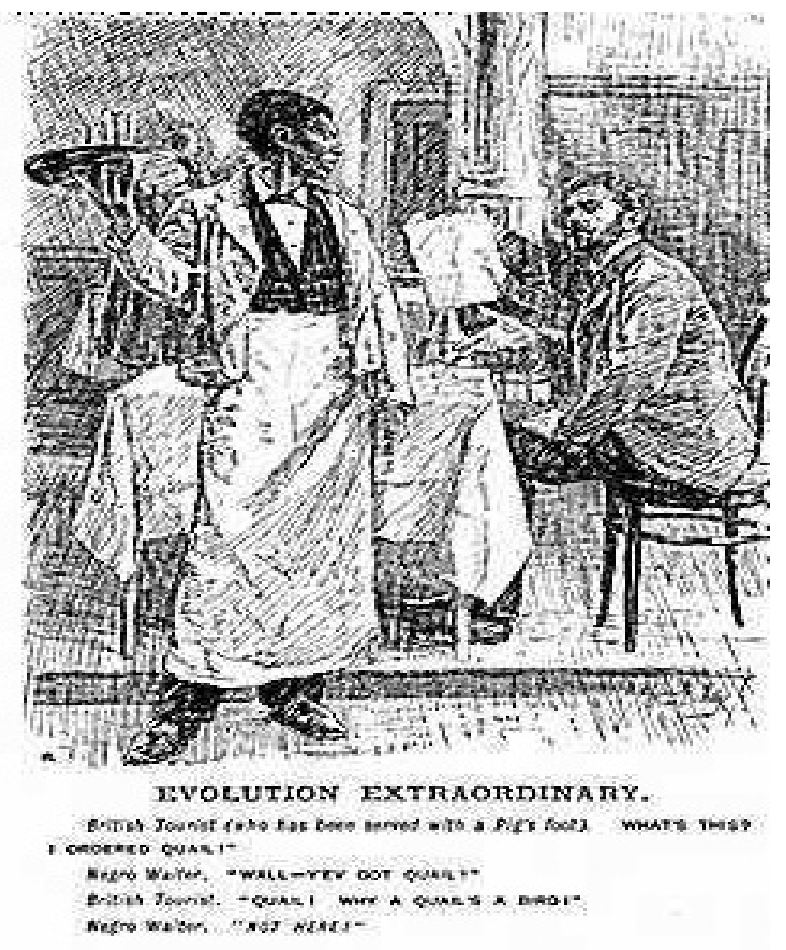

Figure 2. ("Punch")

In terms of both the general atmosphere of the era and such Social Darwinists' contribution to an intellectually biased ideology, Marvin Perry's observation should be underlined: he argues in his Western Civilization that "[w] hereas the philosophers emphasized human equality, Social Darwinists divided humanity into racial superiors and inferiors and whereas the philosophers believed that states would increasingly submit to the rule of law, to reduce violent conflicts, Social Darwinists regarded racial and national conflict as a biological necessity, a law of history, and a means to progress" $(2008,640)$.

As deduced from historical traces, the establishment of both imperialism and colonial discourse was not a coincidence. They took form gradually over time along with the increase in navigational mappings, trading, and scientific inquiries. Consequently, presumptions regarding "the other", and its image on the mind, can be summed up as follows: when Europe, particularly Britain, rediscovered some indigenous peoples in nineteenth century, it did so through the eyes of men who, like their countrymen, were supremely confident that European civilization had reached the highest achievements of man. Moreover, Europe was reinforced in its inspiring confidence by the evolutionary ideas of Charles Darwin and later social Darwinists. Their view was so harsh that the alternatives were stark -'survive or die'. In this sense, Darwin provided the scientific proof of European superiority, a result of which European attitudes toward the nonEuropean were tinted and tainted by this evolutionary theory until the end of World War II. Thus, firstly through classificatory theories and then with the aid of Social Darwinism; travellers, traders, administrators, missionaries and scholars all reflected these prejudices in their relationships with non-westerners and accordingly concretized the image of "the other" as a sort of "quintessence of evil" (Fanon, 1963, 41). 


\section{REFERENCES}

Blake, A. (1989). Reading Victorian Fiction: The Cultural Context and Ideological Context of the Nineteenth-Century Novel. London: The Macmillan Press Ltd.

Blanchard, P. (2005). "From human zoos to colonial apotheoses: the era of exhibiting the Other". Africacultures, October 28, 19-26.

Burke, G. J. (1994). The Wild Man's Pedigree. Oxford: Oxford UP.

Canny, N. (1998). The Origins of Empire: British Overseas Enterprise to the Close of the Seventeenth Century. The Oxford History of the British Empire. Ed. Louis, W. R. (Vols. 5).. Oxford: Oxford UP.

Curtin, P. (1975). The Image of Africa. Madison: Wisconsin UP.

Deirdre, D. (1995). Rule Britannia: Women, Empire, and Victorian Writing. Ithaca: Cornell UP.

Fanon, F. (1963). The Wretched of the Earth. Trans. Constance Farrigton. New York: Grove.

Grafton, A. (1992). New Worlds, Ancient Texts: The Power of Tradition and The Shock of Discovery, Harvard UP.

Leech, J. (1846) Catalogue Reference: csl2296. Retrieved 19 Feb 2010 from http://www.cartoonstock.com/ vintage/cartoonview.asp?start $=\&$ search $=$ vintage\&catref $=$ csl2296\&VC_Category $=$ Not + Selected\&AN Dkeyword=evolution\&ORkeyword=\&TITLEkeyword=\&NEGATIVEkeyword=

Lorimer, D. (1988). “Theoretical Racism in late Victorian Anthropology, 1870-1900”. Victorian Studies, 31, 89-96.

Marshall, P. J. (1998). "The British in Asia: Trade to Dominion, 1700-1765. The Eighteenth Century". The Oxford History of the British Empire, 2. Ed. Louis, W. R. Oxford: Oxford UP.

Partridge, J. B. (1893) Catalogue Reference: csl3572. Retrieved 19 Feb 2010 from http://www.cartoonstock. $\mathrm{com} /$ vintage/cartoonview.asp? start $=4 \&$ search $=$ vintage $\&$ catref $=$ csl3572\&VC_Category $=$ Not + Selecte $\mathrm{d} \&$ ANDkeyword=man+served+pig+foot\&ORkeyword=\&TITLEkeyword=\&NEGATIVEkeyword

Perry, M., \& Jacob, M. (2008). Western Civilization: Ideas, Politics and Society: Since 1400 (9th ed.). Boston, Wadsworth Pub. Co.

Poliakov, L. (1974). Aryan Myth: A History of Racist and Nationalist Ideas in Europe. New York, NY: Basic Books.

Porter, A. (1999). Introduction. The Oxford History of the British Empire: The Nineteenth Century. Oxford: Oxford UP.

Pratt, M. L. (1992). Imperial eyes: Travel Writing and Transculturation. London and New York: Routledge.

Tucker, W. (2002). The Funding of Scientific Racism: Wickliffe Draper and the Pioneer Fund. Urbana, IL: Illinois UP.

Rodney, W. (1982). How Europe Underdeveloped Africa. Washington, DC: Howard UP. 